\title{
Pembelajaran Proyek Berbasis Budaya Lokal untuk Menstimulasi Kecerdasan Majemuk Anak Usia Dini
}

\author{
Siwi Widiastuti \\ pedagogiayk@gmail.com \\ KB DAN TK Laboratori Pedagogia FIP UNY
}

\begin{abstract}
Abstrak
Anak usia dini bersifat unik dan memiliki potensi yang luar biasa. Kecerdasan dan keterampilan yang dimiliki anak dapat berguna bagi perkembangan dan kehidupan mereka. Suatu stimulasi yang salah dapat mempengaruhi kecerdasan dan keterampilan. Ada beberapa aspek yang mempengaruhi pengalaman anak-anak. Diantaranya lingkungan yang kondusif, aman dan nyaman, sebuah pembelajaran yang menarik, menyenangkan dan menantang, yang menggunakan seluruh panca indera dan tubuh anak. Proses pembelajaran dan pengalaman mempengaruhi perkembangan kecerdasan anak diantaranya adalah dengan pembelajaran berbasis multiple intelligences. Karakteristik pembelajaran yang dipilih adalah proyek pembelajaran berbasis budaya lokal untuk merangsang kecerdasan anak. Pembelajaran ini akan memberikan variasi yang menyenangkan dalam suasana belajar. Pembelajaran proyek adalah sebuah metode yang memberikan anak-anak untuk mengeksplorasi lima indera dan tubuh dalam melakukan aktivitas tertentu dengan menyenangkan. Materi tentang budaya dapat menjadi dasar dalam belajar. Budaya mengajarkan anak-anak tentang nilai-nilai budaya, sehingga mereka memahami lingkungan budaya (budaya lokal). Sebuah perilaku baru dan budaya yang tidak sesuai dengan filosofi Indonesia dapat memberikan dampak yang tidak baik terhadap perkembangan anak usia dini. Permasalahan ini dapat diatasi salah satunya dengan menanamkan nilai-nilai budaya lokal untuk anak usia dini.
\end{abstract}

Kata kunci: Anak Usia Dini, Budaya Lokal, Proyek Pembelajaran, multiple intelligences

\begin{abstract}
Intelligence of early childhood is unique and has incredible potential. All early childhood furthermore, the children intelligences and skill can be useful for their development and their life. A wrong stimulation influences the children intelligence and skill that can't be repeated for correcting. There are many aspects that give many experiences for children. They are a condusive, safe and comfortable environment, an interesting, fun and challenging learning, using all five senses and children body. The learning and experience process very affect the children's development intelligences (multiple intelligences). The characteristic of choosen learning is project learning based on local culture to stimulate the children intelligences. It gives variation and fun of learning atmosphere. The project learning is a method that gives the children to explore their five senses and body in
\end{abstract}


doing a certain activity with fun. The culture is as foundation in learning. It will teach the children about culture values so they know their culture environtment (local culture). A new behavior and culture which are inappropriate with Indonesian philosophy give bad effect toward early childhood development. Those can be handled by giving local culture values for early childhood.

Keywords: early childhood, local culture, project learning, multipleintelligences

\section{Pendahuluan}

Pendidikan anak usia dini (PAUD) adalah suatu upaya pembinaan yang ditujukan kepada anak sejak lahir sampai dengan usia enam tahun yang dilakukan melalui pemberian rangsangan pendidikan untuk membantu pertumbuhan dan perkembangan jasmani dan rohani agar anak memiliki kesiapan dalam memasuki pendidikan lebih lanjut (UU No. 20 tahun 2003 tentang SISDIKNAS). PAUD bertujuan mengembangkan berbagai potensi anak sejak dini sebagai persiapan untuk hidup dan dapat menyesuaikan diri dengan lingkunganya.

Program pembelajaran PAUD yang dirancang bertujuan untuk mengembangkan seluruh potensi anak (the whole child) agar kelak dapat berfungsi sebagai manusia yang utuh sesuai budaya dan falsafah suatu bangsa (Slamet Suyanto, 2003). Anak dapat dipandang sebagai individu yang baru mulai mengenal dunia. Anak belum mengetahui tata krama, sopan santun, aturan, norma, etika, dan berbagai hal tentang dunia. Anak juga sedang belajar berkomunikasi dengan orang lain dan belajar memahami orang lain. Anak perlu dibimbing agar mampu memahami berbagai hal tentang dunia dan isinya. Anak juga perlu dibimbing agar memahami berbagai fenomena alam dan dapat melakukan keterampilan-keterampilan yang dibutuhkan untuk hidup di masyarakat. Interaksi anak dengan benda dan dengan orang lain diperlukan untuk belajar agar anak mampu mengembangkan kepribadian, watak, dan akhlak mulia.
Usia dini merupakan saat yang amat berharga untuk menanamkan nilainilai nasionalisme, kebangsaan, agama, etika, moral, disiplin, dan sosial yang berguna untuk kehidupannya dan strategis bagi pengembangan suatu bangsa.

Negara Indonesia merupakan Negara yang terdiri dari berbagai macam suku, ras, budaya, agama, bahasa dan lain sebagainya. Dari berbagai macam perbedaan tersebut tentunya anak perlu memiliki keterampilan dan kemampuan yang baik, agar anak terbiasa untuk menghargai suatu perbedaan sehingga dapat menyesuaikan diri dengan lingkungan. Apalagi di masa era global semua Negara bebas berkunjung ke Negara lain dengan membawa berbagai macam budaya dan kebiasaan. Budaya dan kebiasaan yang datang dari negara lain tentunya ada yang sesuai dan ada yang tidak sesuai dengan Negara Indonesia. Apabila anakanak Indonesia tidak memiliki kemampuan untuk menyaring dan menghargai suatu perbedaan, akan banyak budaya yang ditiru tanpa berpikir itu sesuai atau tidak, selalu ada permusuhan, dan dendam yang tidak baik. Semua itu akan berakibat tidak baik untuk generasi-generasi bangsa dan Negara.

Kehidupan sehari-hari dengan berbagai aktivitas kedua orang tua dan lingkungan masyarakat yang tinggi pada dunia kerja karena kurangnya mendampingi anak-anak bermain sehingga anak-anak cenderung mengisi kegiatan sehari-hari dengan bermain game atau playstation dan melihat televisi dari 
pada bermain dengan teman di lingkungan sekitar. Sarana untuk bersosialisasi dengan orang lain sangat terbatas. Nilai-nilai budaya lingkungan sekitar menjadi pudar digantikan dengan budaya-budaya modern.

Apabila dalam masa era globalisasi tidak ada upaya untuk mengantisipasi, manusia dapat larut dan hanyut di dalamnya. Berkaitan dengan itu, perubahan yang cepat mengharuskan adanya berbagai upaya terhadap anak agar mereka memiliki kemampuan untuk mengantisipasi, mengakomodasi, dan mewarnainya. Salah satu upaya adalah mengaktifkan diri anak dengan nilai-nilai budaya lokal dan menanamkan falsafah bangsa Indonesia agar dapat menyesuaikan diri, menghargai orang lain dan menghargai perbedaan, sehingga dapat diterima oleh lingkungan.

Berbagai kecerdasan majemuk yang dimiliki anak perlu diberikan sarana dan berbagai pengalaman. Sekolah sebagai pendidikan formal yang di dalamnya terdapat proses bela-jar mengajar yang berpengaruh terhadap perkembangan anak. Maka dari itu pembelajaran yang ada perlu adanya pengembangan yang bervariasi, menantang, menarik, menyenangkan dan sesuai dengan perkembangan anak dengan harapan dapat membantu tujuan dari pendidikan.

Dalam rangka upaya untuk meningkatkan pembelajaran membutuhkan perubahan-perubahan berbagai cara dan strategi yang kreatif untuk selalu meningkatkan kecerdasan majemuk yang dimiliki anak. Pendidikan yang lebih baik dapat bermanfaat untuk perkembangan anak dalam rangka membangun manusia yang holistik/ utuh (whole person) yang cakap dalam menghadapi dunia yang penuh tantangan dan cepat berubah, serta mempunyai kesadaran sosial, emosional dan spiritual dengan nilai-nilai budaya lokal yang diterapkan. Pembelajaran yang dipilih yaitu pembelajaran proyek berbasis budaya lokal untuk menstimulasi kecerdasan majemuk anak usia dini.

\section{Pembelajaran Anak Usia Dini}

Anak usia dini belajar dengan caranya sendiri. Satu anak dengan anak yang lain tentunya mempunyai cara masing-masing yang unik sesuai dengan perkembangan dan usianya. Menurut J ohnson and Werner (Harun Rasyid, Mansur, dan Suratno, 2009) bahwa alat indrawi anak terjadi penyesuaian dan rangsangan dari lingkungan. Alat indrawi ini meliputi: tactile (alat peraba dan perasa), visual (penglihatan), auditory (pendengaran), dan motor (gerak). Sebagaimana pendapat De Porter, dan Mike H. (I. Wayan Sutama, 2009) bahwa empat modalitas belajar anak, yakni: (1) visual learner (belajar melalui penglihatan), (2) auditory learner (belajar melalui pendengaran), (3) tactile/kinesthetic learner (belajar melalui perabaan menyentuh, bergerak, dan bekerja), dan (4) global learner (belajar melalui penglihatan, pendengaran, perabaan, menyentuh, bergerak, dan bekerja).

Seluruh aspek perkembangan dan kemampuan anak usia dini dapat distimulasi melalui pembelajaran yang bersifat holistik dan terpadu. Pembelajaran bersifat terpadu (Integrated Learning) yaitu tidak mengajarkan bidang studi secara terpisah (Slamet Suyanto, 2003). Satu kegiatan dapat menjadi wahana belajar berbagai hal bagi anak. Belajar yang efektif jika dapat menggunakan seluruh pengetahuan dan potensi yang dimiliki anak. Semakin banyak keterlibatan indera anak semakin banyak anak memperoleh hasil belajar.

Hal tersebut dikuatkan dengan pendapat Howard Gardner bahwa anak memiliki potensi berupa kecerdasan jamak. Kecerdasan anak akan berkembang secara optimal bila difasilitasi dengan baik dan benar, melalui stra- 
tegi pembelajaran yang sesuai dengan karakteristik dan perkembangannya. Melengkapi pendapat tersebut menurut NAEYC (Amerika Serikat) dalam pembelajaran DAP (Develomentally Appropriate Practices). Slamet Suyanto (2003) menyatakan bahwa kegiatan pembelajaran disesuaikan dengan tingkat usia dalam kelompok usia maupun secara individual. Dengan pembelajaran DAP maka anak akan lebih mudah belajar dalam memperoleh pengalaman. Maka berbagai potensi yang dimiliki anak dapat dikembangkan sesuai dengan usia dan perkembangannya, sehingga semua perkembangan anak dapat terstimulasi dengan baik.

Pembelajaran merupakan suatu upaya untuk menyediakan seperangkat kondisi lingkungan yang dapat merangsang anak untuk melakukan aktivitas belajar. Dalam hal ini, guru berperan menciptakan lingkungan yang kondusif dan dinamis untuk anak belajar. Diuraikan oleh Kamtini dan Husni (2005) ada 4 pilar belajar yang dapat dijadikan acuan dalam mengembangkan pembelajaran, yaitu: (1) belajar untuk memperoleh pengetahuan (learning how to know), (2) belajar untuk mendapatkan keterampilan (learning how to do), (3) belajar untuk membangun jati diri (learning how to be), dan (4) belajar untuk kehidupan bersama (learning how to life together).

Menurut Chen (dalam I. Wayan Sutama, 2009: 7) prinsip dasar dalam pengembangan pembelajaran dalam rangka memfasilitasi perkembangan kecerdasan jamak pada anak, yaitu: (1) holistic development and learning; (2) integrated learning; (3) active learning; (4) supportive learning; (5) learning through interaction; dan (6) learning trough play. Pengembangan kurikulum dan pembelajaran hendaknya berangkat dari pemahaman terhadap perkembangan dan gaya belajar anak usia dini yang bersifat holistik. Pende- katan pembelajaran yang digunakan untuk memfasilitasi karakteristik perkembangan dan belajar anak adalam melalui pembelajaran terpadu. Keterpaduan ini meliputi proses dan materinya, sehingga menghasilkan pembelajaran yang bermakna dan menyenangkan. Pembelajaran yang bermakna dan menyenangkan akan merangsang anak untuk bermain dan belajar secara aktif. Peran guru adalah mendorong terjadinya belajar. Untuk lebih memperluas wawasan dan berkembangnya kemampuan berbahasa dan sosial anak, maka pembelajaran hendaknya memungkinkan anak berinteraksi dengan lingkungannya. Interaksi anak dengan lingkungan dan objekobjek belajar akan memungkinkan anak mengkonstruksi pengalaman belajarnya secara efektif. Mengingat dunia anak usia dini adalah bermain, maka pembelajaran dikemas dalam bentuk permainan kreatif-konstruktif, sehingga anak secara alamiah belajar di balik kegiatan bermain yang dilakukannya.

Bermain sambil belajar, di mana esensi bermain menjiwai setiap kegiatan pembelajaran amat penting bagi PAUD. Sebagaimana menurut Slamet Suyanto (2003) bahwa esensi bermain meliputi perasaan senang, demokratis, aktif, tidak terpaksa, dan merdeka menjadi jiwa setiap kegiatan. Pembelajaran hendaknya disusun sedemikian rupa sehingga menyenangkan, membuat anak tertarik untuk ikut serta, dan tidak terpaksa.

\section{Metode Proyek}

Proyek adalah penelitian sebuah topik yang diperluas dan mendalam yang idealnya merupakan topik yang layak bagi perhatian, waktu, dan energi anak-anak (Roopnarine, J.L dan Johnson, J.E, 2011). Dalam topik tersebut dibutuhkan suatu pendalaman melalui pengetahuan yang memerlukan pemahaman dan perhatian terhadap sebuah topik yang memerlukan jangka waktu tertentu dalam meng- 
kontruksikannya melalui sebuah usaha berupa energi yang tersalur oleh anak. Suatu proyek mempunyai tujuan yang melibatkan suatu pengetahuan, keterampilan, pembawaan dan perasaan. Tujuan tersebut untuk mengembangkan kemampuan berpikir dan pemahaman melalui pengalaman belajar. Pengalaman belajar dapat mendorong anak untuk memecahkan masalah dalam kegiatan sehari-hari dengan mendiri. Kegiatan ini membekali anak mempunyai kreatifitas, memperluas minat anak, dan memadukan kegiatan kerja anak lain dalam mencapai tujuan kelompok.

Metode proyek merupakan strategi pengajaran yang melibatkan anak dalam belajar memecahkan masalah dengan melakukan kerjasama dengan orang lain (Moeslichaton, 2004). Pembelajaran proyek lebih menekankan pada anak mengeksplorasikan pengetahuannya dengan cara menggali rasa ingin tahunya untuk menemukan solusi terhadap permasalahan yang didapatnya. Hal ini sejalan dengan pendapat J ohn Dewey tentang konsep "Learning by doing" bahwa pembelajaran akan bermakna jika disertai tindakan-tindakan sesuai yang akan dicapai. Dalam pembelajaran proyek, guru memberi kesempatan mengeksplorasikan pengetahuan anak melalui pengalaman yang melibatkan kerja masing-masing anak maupun kerjasama dengan anak lain. Guru dalam pelaksanaan pembelajaran proyek lebih memberi kebebasan pada anak dalam beraktifitas yang tidak lepas dari saran-saran yang harus dilakukan sesuai tujuan yang akan dicapai. Dalam pemberian saran, hendaknya guru memberikan informasi yang dapat mendorong daya kreatifitas anak, memberi tantangan dalam bereksplorasi dan menanamkan rasa tangung jawab dalam menyelesaikannya.

Menurut Chard (Roopnarine, J.L dan Johnson, J.E, 2011) meny-atakan bahwa rancangan kegiatan pro-yek dapat dilakukan melalui 3 fase uru-tan yaitu memulai proyek, mengembangkan proyek dan menyelesaikan proyek. Fase memulai proyek guru mendorong anak berbagi pengalaman dan kenangan pribadi terkait dengan topik, meninjau pengetahuan anak, menggunakan representasional dan ekspresif seperti permainan sandiwara, menggambar, melaporkan pengalaman, dan menulis. Fase mengembangkan proyek tujuan utamanya memperoleh informasi baru melalui pengalaman langsung dari dunia nyata seperti darmawisata, kunjungan, dan mendatangkan orang yang memiliki pengalaman yang terkait dengan topik. Fase menyelesaikan proyek yaitu penyelesaian pekerjaan perorangan dan kelompok tentang apa yang telah dipelajari seperti berbagi pengalaman melalui pameran hasil karya, sandiwara dalam pembuatan proyek sebuah toko sepatu atau rumah sakit.

\section{Budaya Lokal dan Implikasi dalam Pembelajaran}

Kebudayaan menurut Prosser (Koentjaraningrat, 2002) yaitu budaya atau kebudayaan (culture) meliputi tradisi, kebiasaan, niai-nilai, norma, bahasa, keyakian, dan berpikir yang terpola dalam suatu masyarakat dan diwariskan dari generasi ke generasi serta memberikan identitas pada komunitas pendukungnya atau dalam rumusan yang lebih sederhana adalah cara kita hidup. Sementara menurut Simatupang (Koentjaraningrat, 2002) budaya dapat didefinisikan secara sempit dan secara luas. Secara sempit mencakup kesenian dengan semua cabang-cabangnya, dan definisi budaya secara luas mencakup semua aspek kehidupan manusia.

Unsur-unsur kebudayaan meliputi semua kebudayaan yang ada di dunia, baik yang kecil, sedang, besar maupun yang kompleks. Tujuanya pengenalan kebudayaan agar belajar anak sesuai dengan lingkungan yang 
ada, selain itu untuk membekali anak hidup pada masa sekarang terutama hari ini, dan sebagai bekal untuk hidup kemudian di masyarakat. Menurut pendapat Malinowski (Koentjaraningrat, 2002) kebudayaan di dunia mempunyai tujuh unsur universal yaitu; 1 ) bahasa; 2) sistem teknologi; 3) sistem mata pencaharian; 4) organisasi sosial; 5) sistem pengetahuan; 6) religi; dan 7) kesenian.

Implikasi dalam pembelajaran diterapkan dalam tema, sub tema, materi atau kegiatan, APE, media, dan peralatan yang mengacu pada unsurunsur kebudayan di lingkungan sekitar anak tinggal. Pengembangan muatan budaya lokal dapat terlihat dalam tabel 1.

\begin{tabular}{|c|c|c|c|}
\hline $\begin{array}{c}\text { Unsur } \\
\text { kebudayaan }\end{array}$ & Tema & Materi & J aringan yang dikembangkan \\
\hline 1. Bahasa & $\begin{array}{l}\text { Tanah Airku } \\
\text { "Bahasa J awa”" }\end{array}$ & $\begin{array}{l}\text { Bahasa } \\
\text { daerahku } \\
\text { Bahasa } \\
\text { temanku } \\
\text { Cerita } \\
\text { daerah }\end{array}$ & $\begin{array}{l}\text { - Mengenal bermacam-macam bahasa } \\
\text { - Menggunakan dalam sehari-hari } \\
\text { - Menghargai perbedaan } \\
\text { - Mendatangkan orang tua anak untuk } \\
\text { belajar bahasa daerah asal } \\
\text { - Cerita rakyat/ dongeng } \\
\text { - Pemutaran film budaya } \\
\end{array}$ \\
\hline $\begin{array}{l}\text { 2. Sistem } \\
\text { Teknologi }\end{array}$ & $\begin{array}{l}\text { Komunikasi } \\
\text { "Kenthongan" }\end{array}$ & $\begin{array}{l}\text { Alat-alat } \\
\text { komunika } \\
\text { si }\end{array}$ & $\begin{array}{l}\text { - Manfaat dan kerugian } \\
\text { - Cara menggunakan } \\
\text { - Tempat membeli dan menjual } \\
\text { - Perawatan, tempat reparasi } \\
\text { - Praktik membuat alat komunikasi } \\
\text { sederhana } \\
\text { - Kunjungan tempa pembuat alat } \\
\text { komunikasi }\end{array}$ \\
\hline $\begin{array}{l}\text { 3. Sisem Mata } \\
\text { Pencaharia } \\
\mathrm{n}\end{array}$ & $\begin{array}{l}\text { Pekerjaan } \\
\text { "Pasar } \\
\text { tradisional" }\end{array}$ & $\begin{array}{l}\text { Penjual } \\
\text { makanan }\end{array}$ & $\begin{array}{l}\text { - Tugasnya } \\
\text { - Peralatan yang digunakan } \\
\text { - Tempat bekerja } \\
\text { - Cara memasak } \\
\text { - Praktek mempersiapkan memasak } \\
\text { - Kerja sama orang tua anak belajar cara } \\
\text { memasak di rumah atau di sekolah } \\
\text { - Mengenalkan berbagai makanan } \\
\text { tradisional” }\end{array}$ \\
\hline
\end{tabular}




\begin{tabular}{|l|l|l|l|}
\hline 4. Organisasi & $\begin{array}{l}\text { Kehidupan di dial } \\
\text { kota dan di } \\
\text { desa }\end{array}$ & $\begin{array}{l}\text { Jalan- } \\
\text { jalan di } \\
\text { sekitar } \\
\text { sekolah }\end{array}$ & $\begin{array}{l}\text { - Mengenal situasi lingkungan } \\
\text { - Kegiatan sehari-hari yang dilakukan } \\
\text { orang } \\
\text { - Kunjungan ke rumah penduduk di } \\
\text { sekitar sekolah } \\
\text { - Atau kunjungan ke rumah teman yang } \\
\text { dekat dan dapat dijangkau }\end{array}$ \\
\hline $\begin{array}{l}\text { 5. Sistem } \\
\text { pengetahua }\end{array}$ & Alam Semesta & $\begin{array}{l}\text { Gejala } \\
\text { Alam } \\
\text { (Banjir, } \\
\text { tanah } \\
\text { longsor, } \\
\text { gunung } \\
\text { meletus) }\end{array}$ & $\begin{array}{l}\text { - Proses terjadinya } \\
\text { - Akibat yang ditimbulkan } \\
\text { - Cara penanggulangan }\end{array}$ \\
6. Raerah yang rawan bencana \\
Religi
\end{tabular}

Tabel 1. Pengembangan muatan budaya lokal

\section{Kecerdasan Majemuk (Multiple Intelligences)}

Pendapat Howard Gardner tentang kecerdasan majemuk menunjukkan bahwa tidak ada satupun kegiatan manusia yang hanya menggunakan satu macam kecerdasan melainkan seluruh kecerdasan yang dimiliki. Semua kecerdasan bekerja sama sebagai satu kesatuan yang utuh dan terpadu. Selain itu anak belajar sesuai dengan karakteristik individu dan tahap usia masing-masing. Pembelajaran dirancang untuk menstimulasi kecerdasan majemuk(Multiple Intelligence).

Menurut Howard Gardner (Paul, 2004: 19) mengemukakan Sembilan macam jenis intelligensi yang perlu mendapatkan perhatian sejak anak usia dini. Kemampuan ini sering disebut kecerdasan ganda atau kecerdasan majemuk. Sembilan kecerdasan majemuk meliputi: (1) musical/rhythmic intelligence, (2) bodily/kinesthetic intelligence, (3) logical/mathematical intelligence, (4) verbal/linguistic, (5) visual/spatial intelligence, (6) inter personal intelligence, (7) intra personal intelligence, (8) naturalist intelligence, (9) eksistensial.

Implementasi kecerdasan majemuk (multiple intelligence) dilakukan sejak dini membantu penelusuran bakat dan potensi anak kelak untuk melanjutkan ke pendidikan yang lebih tinggi. Jika ini dapat dikembangkan berkelanjutan dalam pendidikan berikutnya akan memungkinkan anak dapat menemukan jalan kehidupan yang sesuai. Beberapa hal yang perlu dilakukan untuk mengimplementasikan multiple intelligence adalah:

1. Perlu memahami tentang multiple intelligence beserta karakteristiknya.

2. Mengelompokkan indikator sesuai dengan jenis intelligence berdasarkan ciri-cirinya.

3. Mengelompokkan peralatan dan jenis permainan sesuai jenis intelligence yang akan dikembangkan. 
4. Mencoba berbagai peralatan yang dikelompokkan sesuai jenis intelligence.

5. Mencoba pengamatan kegemaran anak terhadap jenis peralatan dan jenis kegiatan sesuai jenis intelligence.

6. Mengadakan pengelompokkan anak sesuai jenis intelligence tersebut.

7. Memberikan catatan rekomendasi pada orang tua tentang prediksi jenis intelligence yang perlu mendapatkan dukungan untuk dikembangkan.

8. Kegiatan pembelajaran tetap menstimulasi semua jenis intelligence, akan tetapi ada jenis intelligence tertentu secara khusus dikembangkan sesuai dengan pengelompokan berdasarkan pengamatan.

9. Pertemuan orang tua murid dengan pihak sekolah secara berkala untuk melaporkan perkembangan anak sesuai jenis intelligence.

Implikasi dalam pembelajaran kecerdasan majemuk (Multiple Intelligence) dengan kegiata bermain dan permainan dapat digambarkan sebagai berikut beserta ciri-cirinya:

\begin{tabular}{|c|c|c|}
\hline $\begin{array}{l}\text { Kecerdasan } \\
\text { yang distimulasi }\end{array}$ & $\begin{array}{l}\text { Ciri-ciri Kecerdasan Majemuk } \\
\text { (Kemampuan Menonjol Terkait) }\end{array}$ & $\begin{array}{l}\text { Jenis Bermain dan } \\
\text { Permainan }\end{array}$ \\
\hline 1. Bahasa & $\begin{array}{l}\text { - Mengerti urutan dan arti kata-kata } \\
\text { - Menjelaskan, mengajar, bercerita, } \\
\text { - } \text { Herdebat } \\
\text { - Menor } \\
\text { - Analingat dan menghafal } \\
\text { - Menulis dan berbicara } \\
\text { - Main drama, berpuisi, berpidato } \\
\text { - Mahir dalam perbendaharaan kata }\end{array}$ & $\begin{array}{l}\text { Bermain kartu huruf dan } \\
\text { gambar } \\
\text { Bermain tebak gambar }\end{array}$ \\
\hline 2. Logis matematis & $\begin{array}{l}\text { - Logika } \\
\text { - Reasoning, pola sebab-akibat } \\
\text { - Klasifikasi dan kategorisasi } \\
\text { - Abstraksi, simbolisasi } \\
\text { - Pemikiran induktif dan deduktif } \\
\text { - Menghitung dan bermain angka } \\
\text { - Pemikiran ilmiah } \\
\text { - Problem solving } \\
\text { - Silogisme }\end{array}$ & Bermain cerita teka-teki \\
\hline
\end{tabular}




\begin{tabular}{|c|c|c|}
\hline 3. Visual spasial & $\begin{array}{l}\text { - } \text { Mengenal relasi benda-benda dalam } \\
\text { - Puang dengan tepat } \\
\text { - Punya persepsi yang tepat dari } \\
\text { berbagai sudut } \\
\text { - Representasi grafik } \\
\text { - Manipulasi gambar, menggambar } \\
\text { - Mudah menemukan jalan dalam } \\
\text { - Iuang } \\
\text { - Pekajinatif aktif } \\
\text { - Peka terhadap warna, garis, bentuk }\end{array}$ & $\begin{array}{l}\text { Bermain membangun dan } \\
\text { kreatif dengan balok, lego }\end{array}$ \\
\hline 4. Musikal & $\begin{array}{l}\text { - Kepekaan terhadap suara musik } \\
\text { - Tahu struktur music dengan baik } \\
\text { - Mudah menangkap musik } \\
\text { - Mencipta melodi } \\
\text { - Peka dengan intonasi, ritmik } \\
\text { - Menyanyi, pentas musik } \\
\text { - Mencipta musik } \\
\text { - Pemain alat musik } \\
\end{array}$ & Bermain lagu dan gerak \\
\hline 5. Interpersonal & $\begin{array}{l}\text { - Mudah kerjasama dengan teman } \\
\text { - Mudah mengenal dan membedakan } \\
\text { - } \text { Kerasaan dan pribadi teman } \\
\text { - Peka terhadap teman, empati } \\
\text { - Suka memberikan feedback }\end{array}$ & $\begin{array}{l}\text { Bermain jamuran dan } \\
\text { dolanan anak yang lain }\end{array}$ \\
\hline 6. Intrapersonal & $\begin{array}{l}\text { - } \text { Dapat berkonsentrasi dengan baik } \\
\text { - Kesadaran dan ekspresi perasaan- } \\
\text { perasaan yang berbeda } \\
\text { - Pengenalan diri yang dalam } \\
\text { - Keseimbangan diri } \\
\text { - Kesadaran akan realita spiritual } \\
\text { - Reflektif, suka kerja sendiri } \\
\end{array}$ & $\begin{array}{l}\text { Bermain drama tentang } \\
\text { “Salon Bagus”atau } \\
\text { bermain peran potong } \\
\text { rambut atau rias wajah }\end{array}$ \\
\hline 7. Naturalist & $\begin{array}{l}\text { - Mengenal flora dan fauna } \\
\text { - Mengklasifikasi dan identifikasi } \\
\text { tumbuh-tumbuhan dan binatang } \\
\text { - Suka pada alam } \\
\text { - Hidup di luar rumah }\end{array}$ & $\begin{array}{l}\text { Bermain dengan burung } \\
\text { Bermain air }\end{array}$ \\
\hline 8. Kinesthetic & $\begin{array}{l}\text { - Mudah berekspresi dengan tubuh } \\
\text { - Mengaitkan pikiran dan tubuh } \\
\text { - Kemampuan main mimic } \\
\text { - Main drama, main peran } \\
\text { - Aktif bergerak, olahraga, menari } \\
\text { - Koordinasi dan fleksibilitas tubuh } \\
\text { tinggi }\end{array}$ & $\begin{array}{l}\text { Bermain panjat memanjat, } \\
\text { bermain ayunan, meniti } \\
\text { titian, berlari, bermain } \\
\text { bola dll }\end{array}$ \\
\hline 9. Eksistensial & $\begin{array}{l}\text { - Kepekaan dan kemampuan untuk } \\
\text { menjawab persoalan eksistensi } \\
\text { manusia; apa makna hidup ini; } \\
\text { mengapa kita lahir dan mati } \\
\end{array}$ & $\begin{array}{l}\text { Bermain dengan alam, } \\
\text { dan makhluk ciptaan } \\
\text { Tuhan }\end{array}$ \\
\hline
\end{tabular}

Tabel 2. Ciri-ciri, materi dan jenis permainan mengacu pada Kecerdasan Majemuk (Multiple Intelligence) 


\section{Rancangan Pembelajaran Proyek Berbasis Budaya Lokal untuk Menstimulasi Kecerdasan Maje- muk Anak Usia Dini}

Hal-hal yang perlu diperhatikan dalam merancang pembelajaran proyek berbasis budaya lokal untuk menstimulasi kecerdasan majemuk anak usia dini adalah sebagai berikut:

1. Menentukan tema yang sesuai dengan budaya lokal anak. Tema yang dipilih disesuaikan lingkungan anak dengan memperhatikan kedekatan, kesederhanaan, kemenarikan, dan keinsidentalan. Tema juga dapat ditentukan dengan melihat hari-hari tertentu yang berhubungan dengan perayaan-perayaan budaya. Tema yang akan digunakan tentunya juga berkaitan dengan materi, kegiatan, dan peralatan yang digunakan.

2. Menentukan tujuan pembelajaran dan indikator-indikator dalam kecerdasan majemuk yang akan digunakan dalam pembelajaran.

3. Memilih materi dan kegiatan pembelajaran yang disesuaikan dengan tema, tujuan, dan indikator.

4. Merencanakan pembelajaran proyek yang akan dilakukan anak-anak.

5. Menentukan dan mempersiapkan alat-alat yang akan digunakan sesuai dengan budaya lokal (lingkungan sekitar).

6. Mempersiapkan media pembelajaran, alat permainan edukatif (APE), dan perlengkapan yang akan digunakan dalam pembelajaran.

7. Membuat setting tempat atau denah tempat untuk pembelajaran baik di dalam maupun di luar ruangan.

8. Membuat administrasi mengajar seperti; rencana kegiatan mingguan (RKM), rencana kegiatan harian (RKH), dan Instrumen penilaian untuk melihat perkembangan anak, dan ketertarikan anak pada pembelajaran budaya lokal.

9. Evaluasi atau refleksi pembelajaran antar guru tentang pembelajaran yang telah dilaksanakan dengan melihat pada perkembangan anak, ketertarikan anak, permasalahan yang muncul, dan cara pendidik mengajar.

Alur pembelajaran proyek berbasis budaya lokal untuk menstimulasi kecerdasan majemuk anak usia dini dapat digambarkan sebagai berikut: 


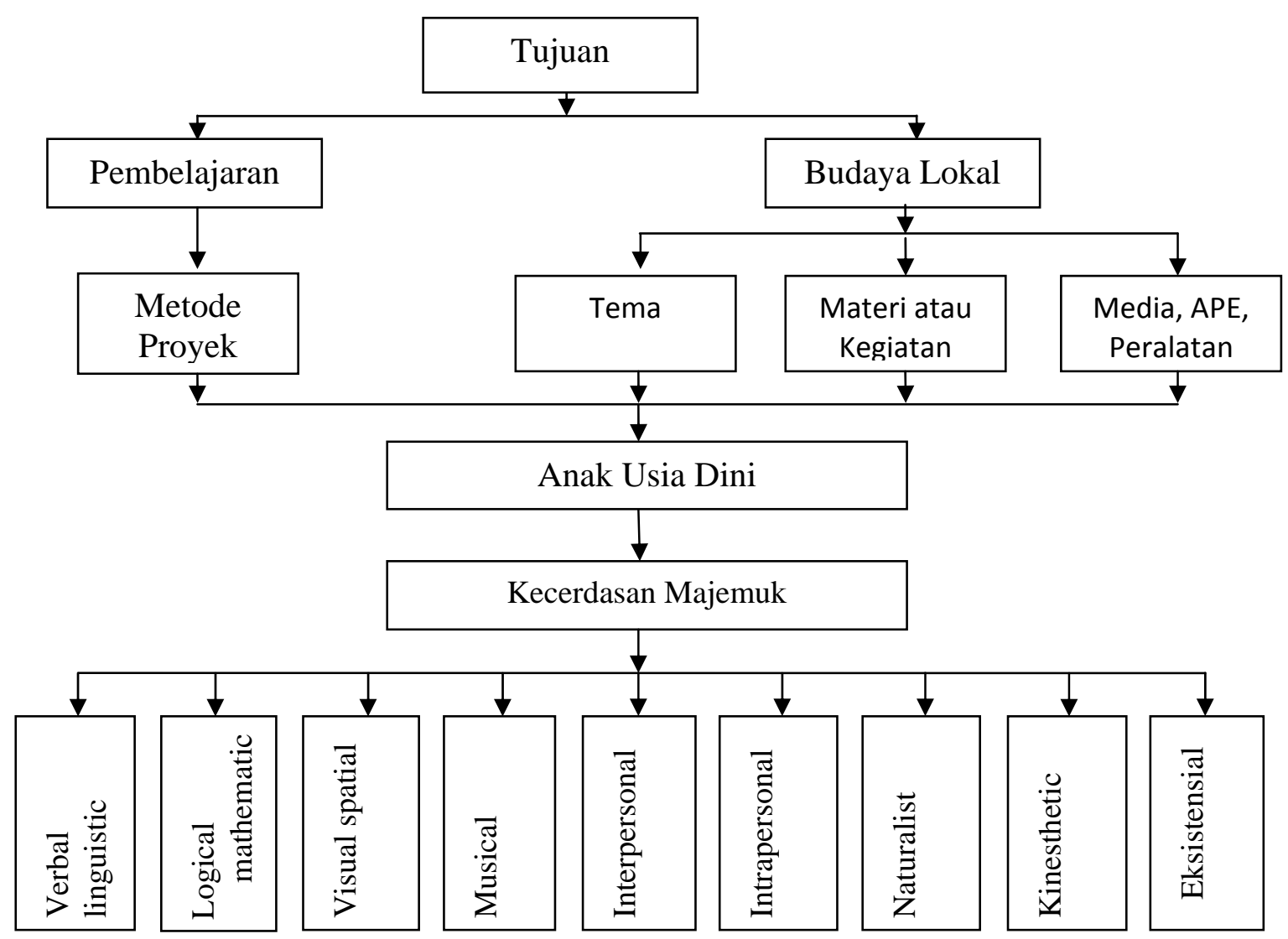

Gambar 1. Alur pembelajaran proyek berbasis budaya lokal untuk menstimulasi kecerdasan majemuk anak usia dini

Contoh rancangan pembelajaran proyek berbasis budaya lokal untuk menstimulasi kecerdasan majemuk anak usia dini yaitu: 


\begin{tabular}{|c|}
\hline $\begin{array}{l}\text { Sub Tema } \\
\text { Macam-macam Kenthongan } \\
\text { Berdasarkan Bentuk dan Ukuran }\end{array}$ \\
\hline $\begin{array}{l}\text { Kegiatan Pembelajaran: } \\
\text { - Bercakap-cakap tentang } \\
\text { "kentongan” meliputi bentuk, dan } \\
\text { ukuran. } \\
\text { - Membuat kentongan bentuk cabe } \\
\text { dari tanah liat. } \\
\text { - Mengelompokkan berbagai macam } \\
\text { gambar kentongan berdasarkan } \\
\text { warna, bentuk, dan ukuran 5-7 } \\
\text { seriasi. } \\
\text { - Mengamati bentuk-bentuk } \\
\text { kentongan dengan cara meraba, } \\
\text { melihat, mencoba kemudian } \\
\text { menggambar, da mewarnai. } \\
\text { - Bermain puzzle dengan gambar } \\
\text { kentongan. } \\
\text { - Gerak lagu “Podo Kumpul” }\end{array}$ \\
\hline $\begin{array}{c}\text { Sub Tema } \\
\text { Bahan Baku Kenthongan }\end{array}$ \\
\hline $\begin{array}{l}\text { Kegiatan Pembelajaran: } \\
\text { - Bercakap-cakap tentang bahan } \\
\text { "kentongan” yaitu dari pohon } \\
\text { bambu, kelapa, waru dan lain-lain. } \\
\text { - Menghubungkan gambar kentongan } \\
\text { dengan bahan dasarnya dengan cara } \\
\text { melompati simpai. } \\
\text { - Mewarnai gambar pohon bambu, } \\
\text { pohon kelapa, dan pohon waru. } \\
\text { - Mengurutkan gambar (pohon bambu, } \\
\text { pohon waru, dan pohon kelapa) dari } \\
\text { yang terendah ketinggi (6-7 seriasi). } \\
\text { - Bermain kartu kata membentuk } \\
\text { kalimat “Ayah menebang pohon } \\
\text { bamboo menggunakan gergaji”. } \\
\text { - Menyanyikan lagu “Podo Kumpul” }\end{array}$ \\
\hline $\begin{array}{c}\text { Sub Tema } \\
\text { Proses Pembuatan Kenthongan }\end{array}$ \\
\hline $\begin{array}{l}\text { Kegiatan Pembelajaran : } \\
\text { - Melihat film cara pembuatan } \\
\text { - } \text { Menthongan } \\
\text { - Mencocok lubang kentongan } \\
\text { kertas dengan } \\
\text { merekatkan/menempel } \\
\text { - Menghias mainan kentongan } \\
\text { - Bermain kartu kata/ membentuk } \\
\text { kalimat Ayah menebang pohon } \\
\text { bambu menggunakan gergaji } \\
\text { - Mengurutkan proses pembuatan } \\
\text { kentongan melalui gambar } \\
\text { (memilih pohon, menebang } \\
\text { pohon, membersihkan daunnya, } \\
\text { di bentuk kentongan, } \\
\text { menghaluskan kentongan, dan } \\
\text { mengecat kentongan). }\end{array}$ \\
\hline
\end{tabular}

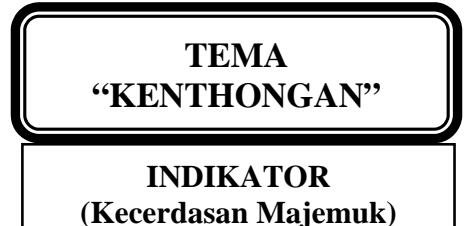

- Dapat bekerjasama dengan teman (Interpersonal)

- Berbuat baik terhadap semua makhluk hidup (Eksistensial)

- Mentaati aturan permainan (Intrapersonal)

- Menceritakan pengalaman/kejadian secara sederhana(Linguistic)

- Menyebutkan symbolsimbol huruf vocal dan konsonan yang dikenal dilingkungan sekitar (Linguistic)

- Menyanyi lebih dari 20 lagu anak-anak (Musical)

- Mengenal perbedaan kasarhalus, berat-ringan, panjang-pendek, jauhdekat, bayak-sedikit, samatidak sama, tebal-tipis, gemuk-kurus, tinggirendah, dsb (Logico Mathematic)

- Mengelompokkan benda dengan berbagai cara menurut ciri-ciri tertentu, missal: menurut warna, bentuk, ukuran (Logico Mathematic)

- Membuat perencanaan kegiatan yang akan dilakukan anak ( Visual Spatial)

- Menciptakan berbagai bentuk menggunakan playdough, tanah liat, pasir ( Visual Spatial)

- Mewarna bentuk gambar sederhana (Visual Spatial)

- Memelihara kebersihan lingkungan, misal tidak mencoret-coret tembok, membuang sampah pada tempatnya dll (Naturalist)

- Membuat berbagai bentuk dari daun, kertas, dan kain perca, kardus dll (Naturalist)

- Mengekspresikan diri dalam gerakan bervariasi dengan lentur dan lincah (Kinesthetic)

- Bermain dengan simpai (Kinesthetic)

- Mencocok bentuk (Kinesthetic)
Sub Tema

Fungsi/Kegunaan Kenthongan

Kegiatan Pembelajaran:

- Bercerita tentang fungsi/kegunaan "kentongan" untuk ronda, mengumpulkan warga bergotong royong, memberi tanda bencana, dan memanggil nelayan.

- Bermain peran tentang ronda dengan kegiatan bermain kartu kata, mendengarkan radio, bermain musik, dan ronda (memukul kentongan keliling kampung)

- Bermain peran gotong royong di lingkungan sekitar dengan kegiatan membersihkan sampah dengan mengelompokkan plastik, kertas, daun, ranting (memukul kentongan untuk mengumpulkan warga)

- Bermain peran menjadi anggota keluarga dengan kegiatan berias, memasak, dan membawa barang-barang ketika ada bencana (memukul kentongan )

- Bermain peran menjadi nelayan dengan kegiatan di perahu sedang memancing, mencari ikan dengan jala, (memukul kentongan memberi tanda memanggil nelayan)

- Menyanyikan lagu "Jeneng Grebeg”

Sub Tema

Membuat Kenthongan dari Bambu

Kegiatan Pembelajaran:

- Tanya jawab bahan-bahan dan peralatan yang digunakan untuk membuat kenthongan

- Membuat kenthongan dengan menghias kentongan

- Menghias pemukul kentongan

- Mengurutkan kentongan dari tinggi ke rendah dalam kelompok masing-masing

- Menggerakkan badan sesuai kesepakatan dengan tanda kentongan yang dipukul yaitu 1 pukulan tenang, 2 pukulan jongkok, 3 pukulan berdiri, dan 4 pukulan lompat

- Menyanyikan lagu “Gotong Royong”

\section{Sub Tema}

Cara Memukul Kenthongan dan Simbol-simbolnya

Kegiatan Pembelajaran:

- Tanya jawab dan tebak suara berbagai bunyi kenthongan

- Bermain dengan kenthongan yaitu menggerakkan badan sesuai kesepakatan dengan tanda kentongan yang dipukul

- Mencoba memukul kenthongan berkelompok dengan berbagai variasi pukulan

- Membuat yel-yel secara berkelompok. 


\section{Penutup}

Pembelajaran yang dilakukan di lembaga sekolah perlu adanya perbaikan-perbaikan, dan inovasi-inovasi baik dari sisi metode pembelajaran, media pembelajaran, maupun alat permainannya, sehingga memberikan suasana pembelajaran lebih menarik dan merangsang rasa ingin tahu pada diri anak. Pembelajaran yang menyajikan berbagai metode pembelajaran akan memberikan berbagai pengalaman pada anak-anak. Pembelajaran proyek sebagai sarana untuk menstimulasi kecerdasan majemuk yang dimiliki anak dengan menanamkan nilainilai budaya lokal melalui tema, subtema, alat permainan edukatif, peralatan, dan media, sehingga perkembangan anak dapat optimal. Pembelajaran tersebut dapat mengembangkan pribadi yang mandiri, percaya diri, dapat menyesuaikan diri, dapat mengembangkan hubungan antar pribadi yang saling memberi dan menerima, serta mau menerima Kenyataan dan mengakui dirinya berbeda dengan anak lain.

\section{Daftar Pusataka}

Budiningsih, Asri. (2006). Strategi Pembelajaran. Yogyakarta: Universitas Negeri Yogyakarta.

Hoerr , Thomas R.. (2007). Buku Kerja Multiple Inelligence. Bandung: PT mizan Pustaka.

Kamtini dan Husni Wardi. (2005). Bermain melalui Gerak dan Lagu di Taman Kanak-Kanak. Jakarta: Direktorat J enderal Pendidikan Tinggi.

Koentjaraningrat. (2002). Pengantar Antropologi Pokok-Pokok Etnografi II. J akarta: PT Rineka Cipta.
Moeslichatoen. (2004). Metode Pengajaran di Taman KanakKanak. Jakarta: Direktorat J enderal Pendidikan Tinggi.

Rasyid, Harun, Mansur, dan Suratno. (2009). Asesmen Perkembangan Anak Usia Dini. Yogyakarta: Multi Pressindo.

Roopnarine, J.L dan Johnson, J.E. (2011). Pendidikan Anak Usia Dini dalam Berbagai Pendekatan (Med. Sari Narulita. Terjemahan). Jakarta: Prenada Media Group.

Suparno, Paul. (2004). Teori Inteligensi Ganda dan Aplikasinya di Sekolah. Yogyakarta: Kanisius.

Sutama, I Wayan. (2009). Pengembangan Multiple Intelligences Pada Anak Usia Dini melalui Pembelajaran yang Mendidik dalam Seminar dan Lokakarya Dosen/ Pengampu S-1 PG-PAUD. Universitas Ronggolawe Tuban 13J uni 2009.

Suyanto, Slamet. (2003). Konsep Dasar Pendidikan Anak Usia Dini. Yogyakarta: Universitas Negeri Yogyakarta. 